\title{
Effects of Tissue Sodium Storage on Plasma Sodium Concentration in Response to Hypo- and Hypertonic Stimuli
}

\author{
Rosa D. Wouda ${ }^{a}$ Rik H.G. Olde Engberink ${ }^{a} \quad$ Eliane F.E. Wenstedt ${ }^{b}$ \\ Jetta J. Oppelaar ${ }^{\mathrm{a}}$ Liffert Vogt ${ }^{\mathrm{a}}$ \\ aDepartment of Internal Medicine, section of Nephrology, Amsterdam University Medical Centers, Amsterdam \\ Cardiovascular Sciences, Amsterdam, The Netherlands; bepartment of Clinical Chemistry, Erasmus Medical Center, \\ Rotterdam, The Netherlands
}

\section{Keywords}

Dysnatremia - Tissue sodium accumulation - Plasma sodium concentration

We have read the second opinion of Nguyen et al. [1] related to our work with interest. Our articles address the potential regulatory function of tissue $\mathrm{Na}^{+}$storage in healthy individuals in response to a hypertonic saline infusion and hypotonic fluid load $[2,3]$. To estimate the effect of tissue $\mathrm{Na}^{+}$storage on plasma $\left[\mathrm{Na}^{+}\right]$, we used formulas derived from the Edelman equation, based on the 2-compartment model for body fluids and solutes [4]. After both interventions, the observed changes in plasma $\left[\mathrm{Na}^{+}\right]$were smaller than changes estimated by the Adrogue-Madias, Barsoum-Levine, and Nguyen-Kurtz formulas [5-7]. Consequently, our results suggest that healthy individuals are able to store or release $\mathrm{Na}^{+}$in response to hyper- and hypotonic stimuli. Short after publication of our findings, a lively discussion was provoked $[8,9]$. Now Nguyen et al. [10] add to this two additional points of criticism. Their main criticisms relate to the estimation of the total body water (TBW) and the imprecise measurement of plasma $\left[\mathrm{Na}^{+}\right]$using the ion-selective electrode (ISE) method. Moreover, to improve accuracy

karger@karger.com
www.karger.com/ne

Karger
(C) 2021 The Author(s).

Published by S. Karger AG, Basel

This is an Open Access article licensed under the Creative Common Attribution-NonCommercial-4.0 International License (CC BY-NC) (http://www.karger.com/Services/OpenAccessLicense), applicable to the online version of the article only. Usage and distribution for commercial purposes requires written permission. in future clinical trials, the authors propose to measure total body exchangeable $\mathrm{Na}^{+}$and $\mathrm{K}^{+}$and TBW with isotope dilution techniques.

The authors state that estimation of the TBW leads to inaccurate calculations of the $\mathrm{Na}^{+}$storage pool. In the study by Olde Engberink et al. [2], the Adrogue-Madias and Nguyen-Kurtz formulas were used to estimate change in plasma $\left[\mathrm{Na}^{+}\right]$. Although we do agree that the use of exact TBW measurements is preferable in an experimental setting, the effect of this inaccuracy on prediction of plasma $\left[\mathrm{Na}^{+}\right]$is limited as we accurately measured changes in TBW, which were independent of (potentially inaccurate) baseline TBW values. We are therefore confident that measurements of TBW would not have influenced the results [2]. Also, when using the Barsoum-Levine and Nguyen-Kurtz formulas, in which TBW is included in both the numerator and denominator $[6,7]$, the effect of baseline TBW on plasma $\left[\mathrm{Na}^{+}\right]$changes is limited. This can be appreciated from the calculations in Table 1 by using the Edelman-based Barsoum-Levine formula with data from Wouda et al. [3]. These calculations reveal after rounding off plasma $\left[\mathrm{Na}^{+}\right]$values practically no difference.

The second point of criticism relates to the imprecision of the ISE method in measurement of plasma $\left[\mathrm{Na}^{+}\right]$. The authors refer to a previous study in which they 
Table 1. Estimated plasma $\left[\mathrm{Na}^{+}\right] 120 \mathrm{~min}$ after water loading according to the Barsoum-Levine formula assuming different TBW values

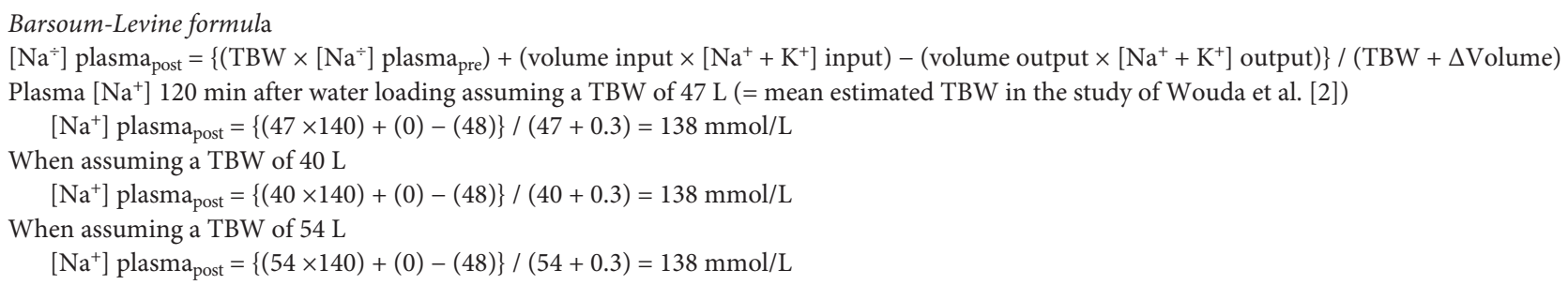

showed that repeated plasma $\left[\mathrm{Na}^{+}\right]$measurements on the exact same sample showed differences ranging from 1 to $3 \mathrm{mmol} / \mathrm{L}$ [10]. They accordingly suggest that the differences in plasma $\left[\mathrm{Na}^{+}\right]$found in the study of Olde Engberink et al. [2] and Wouda et al. [3] are within these limits and therefore may not reflect "true differences." Besides the fact that the authors lump together values of both the direct and the indirect ISE methods (where each has its own analytical performance specifications and only those of the indirect ISE method should be applied to the studies of Olde Engberink et al. [2] and Wouda et al. [3]), more importantly, the range encompasses individual differences. As the imprecision is random and deviations are directed toward both directions, when looking at a group mean comprising more individual persons or samples, the difference moves toward zero. This can also be appreciated when looking at the authors' own data (first table of reference [10]): the deviations occur in both directions, and calculating mean group differences between two measurements on the same sample reveals a mean deviation of $0.09 \mathrm{mmol} / \mathrm{L}$ for the direct ISE and $0.36 \mathrm{mmol} / \mathrm{L}$ for the indirect ISE, being substantially less than the individual differences of $1-3 \mathrm{mmol} / \mathrm{L}$. While in clinical chemistry, increasing efforts are made to reliably assess whether individual differences are "true" or due to analytical or biological variation (together incorporated in the socalled "reference change value" [11]), it is established that in clinical trials (with multiple measurements in multiple people at multiple time points), the effect of analytical and biological variability is significantly attenuated and primarily an issue for measurements in individual patients [12]. Therefore, the observed differences between measured and estimated plasma $\left[\mathrm{Na}^{+}\right]$are unlikely to be explained by imprecision of the ISE method.

Lastly, the authors suggest that in the study by Olde Engberink et al. [2], oral intake of $\mathrm{Na}^{+}$and $\mathrm{K}^{+}$might have influenced the results. However, after saline infusion, intake of food (and subsequent $\mathrm{Na}^{+}$and $\mathrm{K}^{+}$intake) was not allowed. Moreover, as mentioned in the method section,

Effects of Tissue Sodium Storage on

Plasma Sodium Concentration water intake was standardized to $400 \mathrm{~mL}$ and included in the calculation [2].

In the second part of the second opinion, the authors contrast our results to a study by Overgaard-Steensen et al. [13] in which a porcine model of hyponatremia was used. While this model allows precise measurements of the effect of tissue $\mathrm{Na}^{+}$storage on plasma $\left[\mathrm{Na}^{+}\right]$in acute hyponatremia, it lacks translation to human conditions. Particularly, since the total body content of glycosaminoglycans (GAGs), large carbohydrate molecules that enable transient $\mathrm{Na}^{+}$storage, differs among species $[14,15]$. Although studies comparing GAG concentration in tissues between humans and pigs are scarce, one study suggested that the concentration of dermatan sulfate, a sulfated GAG, in the skin is higher in humans than in pigs [16]. In addition, tissue $\mathrm{Na}^{+}$accumulation positively correlates with age and $\mathrm{Na}^{+}$intake [17-19]. Since the pigs were young and fed a supposedly low $\mathrm{Na}^{+}$diet (this was not specified in the publication) [20], the amount of $\mathrm{Na}^{+}$stored may substantially differ from adult males with a habitual high $\mathrm{Na}^{+}$ consumption in the study by Wouda et al. [3]

The authors suggest that to answer the question as to whether changes in plasma $\left[\mathrm{Na}^{+}\right]$can be predicted based on in and output of $\mathrm{Na}^{+}$and $\mathrm{K}^{+}$and TBW in humans, prospective clinical trials are needed in which TBW, $\mathrm{Na}^{+}$, and $\mathrm{K}^{+}$are measured by isotope dilution. It is to be noted that this is in conflict with their suggestion to use the Watson formula to estimate TBW. Moreover, in a study comparing the total body content of water, $\mathrm{Na}^{+}, \mathrm{Cl}^{-}$, and $\mathrm{K}^{+}$ with values obtained by isotope dilution, it was shown that isotope dilution techniques underestimate total body $\mathrm{Na}^{+}$[21]. This discrepancy can be explained by tissue $\mathrm{Na}^{+}$ storage. Yet, whether tissue $\mathrm{Na}^{+}$storage is transient and contributes to modulation of plasma $\left[\mathrm{Na}^{+}\right]$can only be answered by a dynamic intervention. In line with our observations, we hypothesize that after infusion of radioactive $\mathrm{Na}^{+}, \mathrm{Na}^{+}$is stored in tissues, and therefore the dilution volume is larger than can be expected based on TBW.

In this commentary, we have demonstrated that our results are valid, implicating that in response to both 
hypo- and hypertonic stimuli, changes in plasma $\left[\mathrm{Na}^{+}\right]$ cannot be estimated solely based on in and output of $\mathrm{Na}^{+}$ and $\mathrm{K}^{+}$and water, but that $\mathrm{Na}^{+}$stored in tissues should be taken into account. Consequently, clinicians should be aware of the effects of tissue $\mathrm{Na}^{+}$storage.

\section{Acknowledgment}

The authors gratefully acknowledge the help of Johan Fischer (Amsterdam University Medical Centers, Department of Clinical Chemistry) in providing additional information on the ISE method.

\section{Conflict of Interest Statement}

The authors have no conflicts of interest to disclose.

\section{Author Contributions}

R.D.W. drafted the manuscript; R.H.G.O.E., E.F.E.W., J.J.O., and L.V. reviewed and edited the manuscript; L.V. provided supervision.

\section{References}

1 Nguyen MK, Nguyen D, Nguyen M. Can Changes in the Plasma Sodium Concentration Be Predicted Based on the Mass Balance of Sodium, Potassium, and Water in the Face of Osmotically Inactive Sodium Storage? Nephron. 2021.

2 Olde Engberink RH, Rorije NM, van den Born $\mathrm{BH}$, Vogt L. Quantification of nonosmotic sodium storage capacity following acute hypertonic saline infusion in healthy individuals. Kidney Int. 2017 Mar;91(3):738-45.

3 Wouda RD, Dekker SEI, Reijm J, Olde Engberink RHG, Vogt L. Effects of water loading on observed and predicted plasma sodium, and fluid and urine cation excretion in healthy individuals. Am J Kidney Dis. 2019 Sep;74(3):320-7.

4 Edelman IS, Leibman J, O'Meara MP, Birkenfeld LW. Interrelations between serum sodium concentration, serum osmolarity and total exchangeable sodium, total exchangeable potassium and total body water. J Clin Invest. 1958 Sep;37(9):1236-56.

5 Adrogue HJ, Madias NE. Aiding fluid prescription for the dysnatremias. Intensive Care Med. 1997 Mar;23(3):309-16.

6 Barsoum NR, Levine BS. Current prescriptions for the correction of hyponatraemia and hypernatraemia: are they too simple? Nephrol Dial Transplant. 2002 Jul;17(7):1176-80.

7 Nguyen MK, Kurtz I. Determinants of plasma water sodium concentration as reflected in the Edelman equation: role of osmotic and Gibbs-Donnan equilibrium. Am J Physiol Renal Physiol. 2004 May;286(5):F828-37.

8 Adrogue HJ, Madias NE. Nonosmotic $\mathrm{Na}(+)$ storage and the Edelman equation. Kidney Int. 2017 Aug;92(2):514.

9 Adrogue HJ, Madias NE. Osmotically inactivated sodium in acute hyponatremia: stay with Edelman. Am J Kidney Dis. 2019 Sep; 74(3):297-9.

10 Nguyen MK, Ornekian V, Butch AW, Kurtz I. A new method for determining plasma water content: application in pseudohyponatremia. Am J Physiol Renal Physiol. 2007 May; 292(5):F1652-6.

11 Fraser CG. Reference change values. Clin Chem Lab Med. 2011 Sep 30;50(5):807-12.

12 McCormack JP, Holmes DT. Your results may vary: the imprecision of medical measurements. BMJ. 2020 Feb 20;368:m149.

13 Overgaard-Steensen C, Larsson A, Bluhme H, Tonnesen E, Frokiaer J, Ring T. Edelman's equation is valid in acute hyponatremia in a porcine model: plasma sodium concentration is determined by external balances of water and cations. Am J Physiol Regul Integr Comp Physiol. 2010 Jan;298(1):R120-9.

14 Varma RS, Varma R. Glycosaminoglycans and proteoglycans of skin. Glycosaminoglycans and proteoglycans in physiological and pathological processes of body systems. Basel:
Karger; 1982. p. 151-64. https://doi. org/10.1159/000406280.

15 Farber SJ, Schubert M, Schuster N. The binding of cations by chondroitin sulfate. J Clin Invest. 1957 Dec;36(12):1715-22.

16 Fleischmajer R, Perlish JS, Gaisin A. Comparative study of dermal glycosaminoglycans. J Invest Dermatol. 1973 Jul;61(1):1-6.

17 Titze J, Shakibaei M, Schafflhuber M, Schulze-Tanzil G, Porst M, Schwind KH, et al. Glycosaminoglycan polymerization may enable osmotically inactive $\mathrm{Na}+$ storage in the skin. Am J Physiol Heart Circ Physiol. 2004 Jul; 287(1):H203-8.

18 Dahlmann A, Dorfelt K, Eicher F, Linz P, Kopp C, Mossinger I, et al. Magnetic resonance-determined sodium removal from tissue stores in hemodialysis patients. Kidney Int. 2015 Feb;87(2):434-41.

19 Selvarajah V, Maki-Petaja KM, Pedro L, Bruggraber SFA, Burling K, Goodhart AK, et al. Novel mechanism for buffering dietary salt in humans: effects of salt loading on skin sodium, vascular endothelial growth factor $\mathrm{C}$, and blood pressure. Hypertension. 2017 Nov; 70(5):930-7.

20 Council NR. Nutrient requirements of swine. 1998.

21 Forbes GB, Lewis AM. Total sodium, potassium and chloride in adult man. J Clin Invest. 1956 Jun;35(6):596-600. 